\title{
МОТИВАЦИЯ ПРОФЕССИОНАЛЬНОГО ВЫБОРА СТУДЕНТОВ ЮРИДИЧЕСКОГО ФАКУЛЬТЕТА: ТЕОРЕТИКО-ПРАВОВЫЕ ОСНОВЫ
}

\author{
(c) 2021 Иванова Татьяна Михайловна \\ старший преподаватель кафедры теории и истории государства и права \\ Астраханский государственный университет, Россия, Астрахань \\ E-mail: krohmalt@mail.ru
}

(c) 2021 Митячкина Екатерина Сергеевна

кандидат юридических наук, доцент кафедры гражданского права Астраханский государственный университет, Россия, Астрахань

E-mail:miss.mity@mail.ru

\section{(c) 2021 Савельева Елена Викторовна}

доктор исторических наук, профессор кафедры теории и истории государства и права Астраханский государственный университет, Россия, Астрахань

E-mail: law@asu.edu.ru

\section{(c) 2021 Фастова Марина Андреевна}

кандидат юридических наук, доцент кафедры гражданского права Астраханский государственный университет, Россия, Астрахань

E-mail: romanenkoma82@mail.ru

В статье рассматривается механизм привлечения абитуриентов в высшее учебное заведение на примере комплекса мер, реализуемых на юридическом факультете ФГБОУ ВО «Астраханский государственный университет». Проводится детальный анализ влияния проводимых мероприятий, направленных на увеличение количества абитуриентов и формулируются рекомендации по привлечению абитуриентов.

Ключевые слова: высокомотивированный студент, юридический факультет, Школа юного юриста, правовая грамотность, правосознание, Школа юного медиатора, конкурс исследовательских работ, профессиональный выбор.

Деятельность высшего учебного заведения немыслима без отлаженного механизма взаимодействия с обществом, поскольку университет играет архиважную роль в реализации задачи по распространению знаний. При этом первостепенная роль отводится активному взаимоотношению с абитуриентами.

Любое высшее учебное заведение заинтересовано в привлечении прежде всего таких потенциальных студентов, которые будут прилагать усилия для получения новых знаний и умений.

Для понимания того насколько та или иная программа, реализуемая высшим учебным заведением, соответствует требования и ожиданиям абитуриента, необходимо еще до поступления в вуз попытаться погрузится в жизнь соответствующего факультета, что поможет приобрести наиболее точное представление о выбранной программе. Так называемое «полное погружение» абитуриента уже со школьной скамьи в студенческую жизнь вуза является одним из средств достижения цели профессиональной ориентации.

Факультеты высших учебных заведений могут устраивать конкурсы, организовывать олимпиады, конференции, школы, привлекая самих школьников и их родителей, учителей. Информационные системы, применяемые для указанных выше целевых групп, включают в себя прежде всего официальные сайты университетов. Вместе с тем, наряду с традиционными методами привлечения учебные заведения активно используют возможности интернета: создаются группы вузов и их факультетов в социальных сетях, где выкладываются фото- и видеоматериал о жизни вуза/факультета, другие материалы о проводимых мероприятиях. Таким образом, говоря о привлечении абитуриентов на факультет, можно выделить два уровня. Первый включает в себя непосредственную работу со школьниками, а второй - информирование.

В частности, на юридическом факультете 


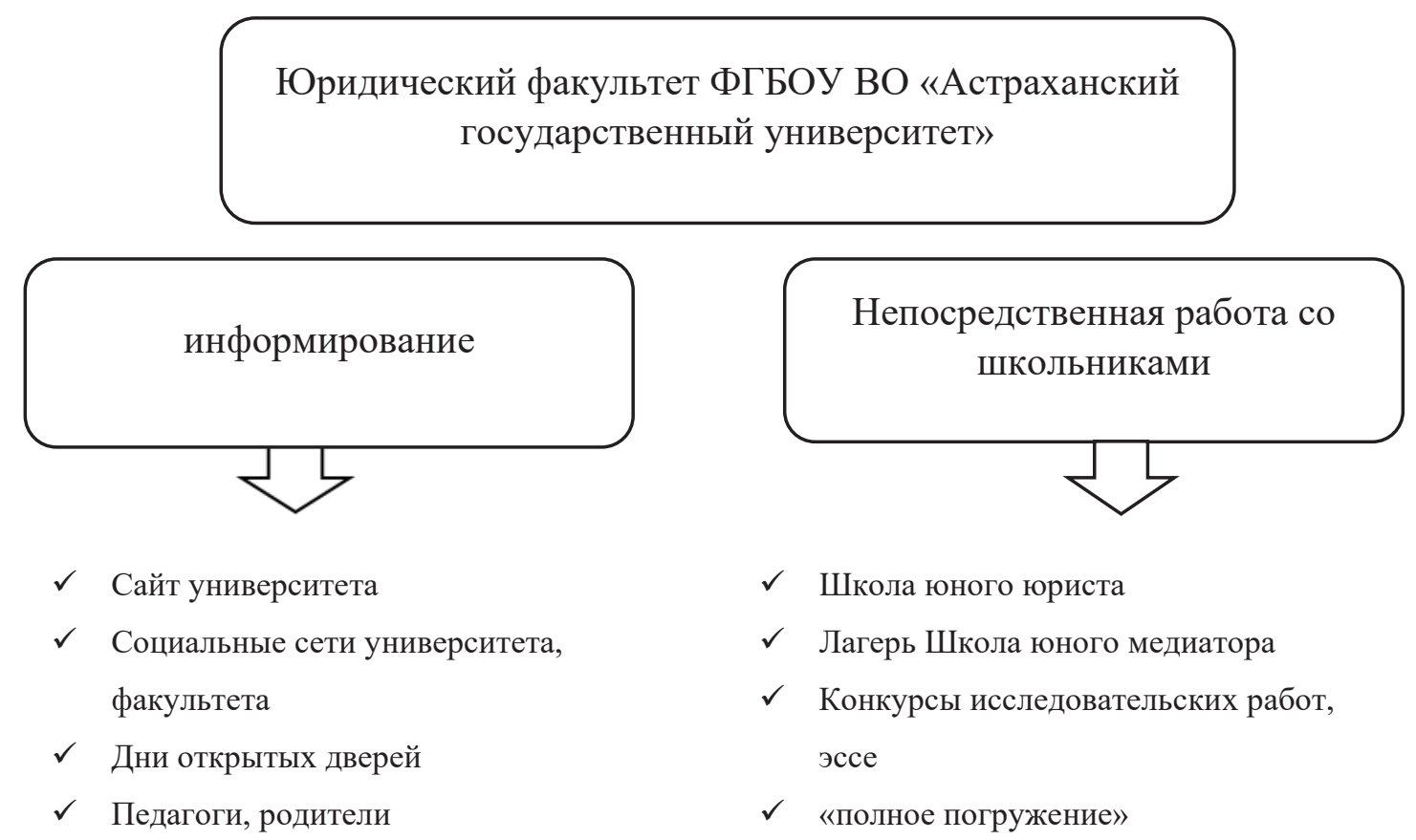

Рuc. 1. Привлечение абитуриентов на юридический факультет ФГБОУ ВО «Астраханский государственный университет»

ФГБОУ ВО «Астраханский государственный университет» с 2017 года функционирует Центр медиации и права, одним из структурных подразделений которого является Школа юного юриста, благодаря чему абитуриенты имеют возможность активно взаимодействовать с университетом задолго до поступления. Именно в этот период с одной стороны школьники начинают жить в атмосфере вуза, а с другой- идет предварительная селекция.

Школа юного юриста представляет собой образовательный проект юридического факультета Астраханского государственного университета, ориентированный на учащихся 8-11 классов. Опираясь на положения Основ государственной политики Российской Федерации в сфере развития правовой грамотности и правосознания граждан», утвержденных Президентом РФ 28.04.2011 N Пр-1168, приоритетными направлениями Школы юного юриста являются с одной стороны развитие правовой грамотности и правосознания, с другой- углубление теоретических и практических знаний в области права.

Вследствие реализации данного образовательного проекта абитуриент получает возможность достоверно понять насколько выбранный факультет ему подходит. Подобный эффект достигается благодаря тому, что занятия для школьников проводятся высококвалифицированны- ми преподавателями юридического факультета Астраханского государственного университета, что дает возможность почувствовать атмосферу одного из лучших вузов России и, как следствие, осознанно выбрать будущую профессию.

Школа юного юриста Астраханского государственного университета позволяет абитуриенту трезво оценить возможности и получить представление об учебе на юридическом факультете еще до поступления в вуз и помогает в реализации преимущества, отмеченного М.А.Плаксиным в своей статье: «Если школьник хотел поступить в данный вуз, он специально готовился к поступлению именно в этот вуз, целенаправленно добывал нужные для этого знания. И тем самым обеспечивал себе преимущество при поступлении. Вуз в результате отбора именно таких абитуриентов получал первокурсников с высокой степенью мотивации и высоким стартовым уровнем» [5].

Более того, большим спросом пользуются и мероприятия, проводимые для родителей слушателей Школы юного юриста, на которых в простой, доступной форме разбираются жизненно важные вопросы, с которыми достаточно часто сталкивается любой человек: защита прав потребителей, вступление в наследство и т.п.

Для повышения мотивации, привлечения внимания к специальностям, реализуемым на 
юридическом факультете Астраханского государственного университета, а также в целях распространения знаний о правах человека, преодоления правового нигилизма детей и молодежи, среди школьников проводится ежегодный конкурс исследовательских работ «Права человека: взгляд юного поколения». Формирование конкурсного жюри для оценивания работ и выступлений заслуживает отдельного рассмотрения, поскольку для наиболее полного, объективного рассмотрения поступивших на конкурс работ приглашаются высококвалифицированные преподаватели юридического факультета Астраханского государственного университета, а также члены Астраханского регионального отделения Общероссийской общественной организации «Ассоциация юристов России».

Так, в 2020/2021 уч.г. десять процентов слушателей Школы юного юриста приняли участие в указанном выше конкурсе, что несомненно позволяет говорить о важности и необходимости проводимого мероприятия.

Кроме того, отдельного внимания заслуживает тот факт, что победители конкурса во время школьных (осенних) каникул приглашаются на занятия, проводимые для студентов юридического факультета Астраханского государственного университета. Так называемое «полное погружение» несомненно является одним из самых продуктивных методов, благодаря которому образовательный процесс университета приоткрывает свою завесу для школьников, обретает яркие краски, открывает новые возможности для будущих студентов.

По статистическим данным каждый двенадцатый студент первого курса юридического факультета Астраханского государственного университета проходил успешное освоение программы курса Школы юного юриста. А отзывы слушателей в социальных сетях свидетельствуют о правильности выбранного факультетом пути привлечения абитуриентов и высокой квалификации преподавательского состава.

Отдельного внимания в вопросе, оказывающем влияние на профессиональный выбор будущими студентами, заслуживает организация и деятельность школьных лагерей в каникулярное время. Так, в грядущем учебном году на базе юридического факультета Астраханского государственного университета планируется открытие лагеря «Школа юного медиатора». Основную цель этого пилотного проекта можно опреде- лить, как практико-ориентированную подготовку, а также популяризацию направлений обучения на юридическом факультете.

Выбор тематики лагеря, посвященной медиации, не случаен. Последнее десятилетие этой альтернативной форме разрешения споров уделяется колоссальное внимание. На наш взгляд внимания заслуживают, прежде всего, два момента. Во-первых, после принятия Федерального закона № 193-Ф3 «Об альтернативной процедуре урегулирования споров с участием посредника (процедуре медиации)» [1], а также на основании Письма министерства образования и науки Российской Федерации от 18.11.2013 г. № ВК-844/07 «О направлении методических рекомендаций по организации служб школьной медиации» [2] произошло повсеместное внедрение в общеобразовательные учреждения служб школьной медиации, являющиеся одним из инструментом урегулирования школьных конфликтов.

Во-вторых, понятие медиации необходимо более активно интегрировать в жизнь общества. Особенно актуальное звучание этот вопрос приобретает в контексте того, что Астраханская область является регионом многонациональным. Более того, в последнее время наблюдается существенный рост интереса к образованию, получаемому иностранными студентами в Российской Федерации. ФГБОУ ВО «Астраханский государственный университет» занимает лидирующие позиции в рейтинге экспорта образовательных услуг. Это связано как с высоким качеством получаемого образования, так и с географической близостью к Астраханской области таких государств как Иран, Казахстан, Туркменистан и др.

Обучение в Школе юного медиатора позволяет решить не только проблему профориентации, но и не допустить возникновение конфликтов, в том числе межнациональных.

Подводя итог сказанному выше следует отметить, что реализация перечисленных программ способствует привлечению для обучения на юридическом факультете Астраханского государственного университета высокомотивированных абитуриентов, что несомненно, по окончании обучения, позволяет говорить о высоком уровне образования выпускников. Кроме того, преимуществом как юридического факультета АГУ, так и вуза в целом, является высокое качество образования и большая востребованность 
выпускников на рынке труда, что подкрепляется информацией о вхождении в список ста лучших вузов России по версии Forbes (2019 г.). В частности, при составлении рейтинга аналитики учитывали не только качество образования, но и статистические данные о трудоустройстве выпускников, их востребованности в регионах, ко- личестве предпринимателей среди них [3]. Еще одним немаловажным показателем является значительный рост показателей Астраханского госуниверситета в Национальном агрегированном рейтинге, обусловленный как достижениями талантливых студентов вуза, так и значимым повышением качества обучения [4].

\section{Библиографический список}

1. ФЗ «Об альтернативной процедуре урегулирования споров с участием посредника (процедуре медиации)» от 27.07.2010 N 193-Ф3 (в ред. от 26.07.2019 N 197-Ф3) // Российская газета от 30 июля 2010 г.- Федеральный выпуск № 168 (5247).

2. Письмо Минобрнауки России от 18.11.2013 N BK-844/07 «О направлении методических рекомендаций по организации служб школьной медиации» (вместе с «Рекомендациями по организации служб школьной медиации в образовательных организациях», утв. Минобрнауки России 18.11.2013 N BK-54/07вн)// Вестник образования. 2014. № 4.

3. АГУ вошёл в список 100 лучших вузов России по версии Forbes// URL: https://asu.edu.ru/news/7977-aguvoshel-v-spisok-100-luchshih-vuzov-rossii-po-versii-forbes.html (дата обращения: 04.07.2021)

4. АГУ поднялся на 71 позицию в ежегодном Национальном агрегированном рейтинге вузов// URL: https:// asu.edu.ru/news/11523-agu-podnialsia-na-71-poziciu-v-ejegodnom-nacionalnom-agregirovannom-re.html (дата обращения: 04.07.2021)

5. Плаксин М.А. Единый госэкзамен лишает вузы права отбора своего абитуриента // Всероссийский съезд учителей информатики в МгУ 2426 марта 2011 года: сб. тезисов докладов.- М: Издательство Московского гос. ун-та, 2011.- с. 25. 